\title{
Pengaruh Likuiditas, Kebijakan Dividen, Profitabilitas, dan Ukuran Perusahaan pada Nilai Perusahaan
}

\author{
Gusti Ayu Putri Cahyani ${ }^{1}$ \\ Ni Gusti Putu Wirawati \\ ${ }^{1,2}$ Fakultas Ekonomi dan Bisnis Universitas Udayana (Unud), Bali, Indonesia \\ e-mail: putricahyani96@gmail.com
}

\begin{abstract}
ABSTRAK
Teori sinyal menekankan bahwa informasi perusahaan dapat direspon berbeda oleh investor. Salah satu metode yang digunakan untuk menganalisis nilai perusahaan adalah menggunakan pendekatan Price to Book Value (PBV). Penelitian ini bertujuan untuk menganalisis pengaruh likuiditas, kebijakan dividen, profitabilitas, dan ukuran perusahaan pada nilai perusahaan. Penelitian ini dilakukan pada perusahaan yang terdaftar dalam indeks LQ 45 di Bursa Efek Indonesia tahun 2013-2016. Jumlah sampel yang diambil sebanyak 10 perusahaan menggunakan metode nonprobability sampling dengan teknik purposive sampling, sehingga jumlah sampel selama 4 tahun pengamatan menjadi 40 perusahaan. Teknik analisis data yang digunakan adalah analisis regresi linier berganda. Hasil analisis menunjukkan bahwa likuiditas dan profitabilitas berpengaruh positif pada nilai perusahaan, sedangkan kebijakan dividen dan ukuran perusahaan tidak berpengaruh pada nilai perusahaan.
\end{abstract}

Kata Kunci: Likuiditas, kebijakan dividen, profitabilitas, ukuran perusahaan, dan nilai perusahaan

\begin{abstract}
Signal theory emphasizes that company information can be responded differently by investors. One method used to analyze company value is using the Price to Book Value $(P B V)$ approach. This study aims to analyze the effect of liquidity, dividend policy, profitability, and firm size on firm value. This research was conducted on companies listed in the LQ 45 index on the Indonesia Stock Exchange in 2013-2016. The number of samples taken as many as 10 companies used the nonprobability sampling method with a purposive sampling technique, so that the number of samples during the 4 years of observation became 40 companies. The data analysis technique used is multiple linear regression analysis. The results of the analysis show that liquidity and profitability have a positive effect on firm value, while dividend policy and company size have no effect on firm value.

Keywords: Liquidity, dividend policy, profitability, company size, and company value
\end{abstract}

\section{PENDAHULUAN}

Tujuan utama perusahaan yaitu untuk meningkatkan nilai perusahaan. Perusahaan yang go public umumnya akan meningkatkan kemakmuran pemegang saham yaitu dengan cara meningkatkan nilai perusahaannya tersebut. Karena nilai perusahaan akan memberi gambaran investor pada 
tingkat keberhasilan perusahaan agar dapat memberikan kemakmuran pemegang saham yang tercermin dari harga sahamnya (Wirasedana 2018). Menurut Surya Lestari (2018) adapun faktor-faktor yang mampu mempengaruhi nilai perusahaan yaitu profitabilitas, leverage, ukuran perusahaan, likuiditas, struktur modal, kebijakan dividen, solvabilitas, pengungkapan Corporate Social Responsibility (CSR) dan penerapan Good Corporate Governance (GCG).

Pencapaian dari suatu perusahaan dapat dilihat dari laporan keuangannya yang menjelaskan informasi keuangan yang dapat dihitung melalui rasio tertentu (Badera and Dewantari 2015). Setiap manajemen harus membuat laporan keuangan sebagai bentuk pertanggungjawaban kepada pihak internal dan eksternal perusahaan. Laporan keuangan merupakan instrumen yang sangat penting karena menyediakan informasi mengenai sumber daya yang dimiliki perusahaan, meliputi posisi keuangan serta kinerja suatu perusahaan. Informasi ini sangat diperlukan oleh investor, kreditur, pemerintah serta pihak lain yang memiliki kepentingan (Attari, 2012).

Perusahaan go public yang terdaftar di Bursa Efek Indonesia umumnya meningkatkan kemakmuran investor melalui peningkatan nilai perusahaan. Nilai perusahaan dibentuk melalui indikator nilai pasar saham yang dipengaruhi oleh investasi. Adanya peluang investasi dapat memberikan sinyal positif tentang pertumbuhan perusahaan di masa depan yang dapat meningkatkan nilai perusahaan (Budi and Putri 2018). Ada tiga jenis nilai saham yang terdiri dari atas nilai buku yang merupakan nilai saham terhadap 
pembukuan emiten, nilai pasar yang merupakan pembukuan nilai dipasar perusahaan dan nilai instristik yang merupakan nilai yang sebenarnya dari saham (Hartono, 2010:76). Investor wajib memahami ketiga nilai tersebut untuk mengetahui saham mana yang mahal dan saham mana yang murah.

Salah satu indikator yang dapat digunakan untuk mengukur nilai instristik adalah menggunakan Price to Book Value (PBV) yaitu perbandingan harga saham dengan nilai buku per saham (Brigham dan Gapensi, 2006). Apabila rasio PBV harga pernilai buku terlalu mahal, maka saham tidak akan menarik investor untuk membelinya Harga saham harus dibuat secara optimal yakni harga saham tidak terlalu tinggi dan juga tidak terlalu rendah. Harga saham yang terlalu rendah tidak akan menarik dimata investor itu memberi gambaran bahwa citra perusahaan tersebut buruk. Harga saham yang optimal, dapat dilihat dari pengalaman perusahaan dalam menjual saham di bursa efek. Bila pasar tertarik membeli saham yang diperdagangkan, maka perusahaan bisa meningkatkan harga saham (Dwipayana and Suaryana 2016).

Rasio price to book value menggambarkan seberapa besar pasar menghargai nilai buku perusahaan, sehingga perubahan harga saham ikut mempengaruhi perubahan nilai price to book value. Keberadaan price to book value dapat dijadikan penentuan strategi investasi di pasar modal karena melalui price to book value, investor dapat memprediksi saham-saham yang overvalued atau undervalued (Wirasedana 2018). Nilai pasar dan nilai buku adalah identik, rasio price to book value lebih dari satu mengindikasikan perusahaan memiliki nilai tambah (Agrawal, 1996). Nilai buku perlembar 
saham menunjukkan aktiva bersih yang dimiliki oleh pemegang saham dengan memiliki satu lembar saham. Harga saham yang meningkat membuat investor tertarik berinvestasi dalam satu perusahaan dengan melihat kenaikan book value pershare artinya kinerja perusahaan juga baik (Malik, et al., 2012). Penelitian yang berkaitan dengan nilai perusahaan telah dilakukan oleh beberapa peneliti. Penelitian tersebut berusaha menemukan faktor yang mempengaruhi nilai perusahaan. Dimana penelitian ini menggunakan faktor likuiditas, kebijakan dividen, profitabilitas, dan ukuran perusahaan. Faktor pertama yang mempengaruhi nilai perusahaan adalah likuiditas. Rasio likuiditas adalah salah satu rasio untuk mengukur kinerja perusahaan. Likuiditas dapat mengukur bagaimana kemampuan suatu perusahaan dalam memenuhi kewajiban jangka pendek dengan cara melihat jumlah aset lancar dengan kewajiban lancarnya. Perusahaan yang memiliki tingkat likuiditas yang tinggi mengindikasikan perusahaan tersebut mampu memenuhi kewajiban jangka pendeknya dengan baik, sebaliknya jika perusahaan memiliki tingkat likuiditas yang rendah mengindikasikan perusahaan tidak mampu memenuhi kewajiban jangka pendeknya dengan baik (Yasa 2016).

Menurut penelitian (Topaloğlu et al. 2010) likuiditas berpengaruh positif terhadap nilai perusahaan pada perusahaan publik di Bursa Efek New York (NYSE). Penelitian ini juga dilakukan di Indonesia diantaranya oleh Yasa (2016) didukung oleh Rompas (2013) menunjukkan bahwa likuiditas berpengaruh postif pada nilai perusahaan, manajer perusahaan perlu menjaga tingkat likuiditas, karena apabila likuiditas baik maka perusahaan akan efektif 
dalam menghasilkan laba yang nantinya akan berdampak pada nilai perusahaan. Penemuan tersebut berlawanan dengan penelitian Astutik (2017) dan Nurhayati dan Buana (2018) yang menemukan bahwa likuiditas tidak berpengaruh pada nilai perusahaan. Brealey dan Myres dalam (Uremadu, 2012) mengatakan bahwa investor akan lebih tertarik terhadap perusahaan yang menghasilkan uang untuk membayar hutang atau kewajibannya.

Faktor kedua yang mempengaruhi nilai perusahaan adalah kebijakan dividen. Dividen merupakan pembagian laba perusahaan kepada para pemegang saham yang besarnya sama dengan jumlah lembar saham yang dimiliki. Pembayaran dividen penting bagi investor karena dividen memberikan kepastian tentang kesejahteraan keuangan perusahaan, dividen menarik bagi investor untuk mengamankan penghasilan saat ini dan dividen mampu menjaga dari harga pasar saham. Adanya dividen akan menambah kekayaan pemegang saham (Adesola and Okwong 2009). Michaely dan Michael (2011) dalam penelitiannya menyebutkan kebijakan dividen adalah segalanya namun tidak relevan terhadap manajer dan pasar.

Penelitian yang berhubungan dengan kebijakan dividen pada nilai perusahaan diantaranya dilakukan oleh Uwuigbe, et al., (2018) mengenai pengaruh dividend payout ratio terhadap kinerja perusahaan pada perusahaan yang listed di Nigeria hasilnya adalah dividend payout ratio berpengaruh positif pada kinerja perusahaan. Penelitian juga dilakukan oleh peneliti di Indonesia diantaranya oleh (Dwipayana and Suaryana 2016), Senata (2016) serta Wirasedana (2018) mengatakan kebijakan dividen berpengaruh positif 
terhadap nilai perusahaan. Hasil penelitian berbeda ditemukan oleh Nurhayati dan Buana (2018), serta Dewi dan Putri (2017) yang menyatakan kebijakan dividen tidak berpengaruh pada nilai perusahaan.

Faktor ketiga yang mempengaruhi nilai perusahaan adalah profitabilitas. Profitabilitas sangat penting untuk perusahaan apabila akan membagikan dividen karena profitabilitas diartikan sebagai kemampuan perusahaan untuk menghasilkan laba atau profit dalam upaya meningkatkan nilai perusahaan (Gryglewicz 2011). Profitabilitas mempengaruhi kebijakan dividen karena profitabilitas merupakan kemampuan perusahaan untuk menghasilkan laba dan dividen akan dibagi apabila perusahaan tersebut meperoleh laba. Profitabilitas adalah keuntungan bersih setelah bunga dan pajak, keuntungan tersebut yang layak dibagi kepada pemegang saham (Octaviani and Astika 2016). Profitabilitas diproksikkan dengan Return on Assets (ROA) yang mengukur kemampuan dari modal yang diivestasikan dalam keseluruhan aktiva untuk menghasilkan neto. Nilai ROA yang tinggi akan memberi sinyal positif bagi investor untuk dapat memprediksi bahwa prospek perusahaan dalam masa depan sangat menguntungkan (Izah and Ahmad 2011). Hal ini dapat meningkatkan daya tarik perusahaan kepada investor.

Penelitian dilakukan oleh Dewi dan Wirawati 2018)) menyatakan bahwa profitabilitas berpengaruh positif pada nilai perusahaan diperkuat dengan penelitian Sudiyatno (2012). Namun hasil lain ditemukan oleh (Susianti dan Yasa 2013) mendapatkan hasil ROA tidak berpengaruh terhadap nilai perusahaan. 
Faktor keempat yang mempengaruhi nilai perusahaan adalah ukuran perusahaan. Penelitian yang dilakukan oleh Gill and Obradovich (2012) menyatakan bahwa ukuran perusahaan berpengaruh positif dan signifikan terhadap nilai perusahaan. Ukuran perusahaan dapat memberi gambaran kemampuan finansial perusahaan dalam suatu periode tertentu. Ukuran perusahaan mencerminkan aset yang dimiliki oleh perusahaan. Umunya perusahaan yang besar akan memiliki nilai aset yang lebih tinggi dibandingkan dengan perusahaan yang kecil sehingga perusahaan besar lebih mudah masuk pasar modal. Perusahaan besar memiliki banyak banyak unit usaha serta memiliki potensi yang baik untuk meningkatkan tujuan jangka panjang perusahaan yaitu meningkatkan nilai perusahaan. Perusahaan besar juga akan mendapat perhatian dari stakeholders yang berkepentingan. Stakeholders akan memberi perhatian lebih terhadap aktivitas perusahaan (Suniari dan Suaryana 2017).

Penelitian tentang ukuran perusahaan dilakukan oleh Pratama dan Wiksuana (2016) menyatakan bahwa ukuran perusahaan berpengaruh positif signifikan pada nilai perusahaan. Ukuran perusahaan menggambarkan besar kecilnya suatu perusahaan, semakin besar ukuran suatu perusahaan menunjukkan bahwa perusahaan tersebut mengalami perkembangan. Hal tersebut akan meningkatkan nilai perusahaan dan kelak direspon positif oleh para investor terhadap nilai perusahaan selaras dengan Prasetyorini (2013). Namun hasil penelitian berbeda yang dilakukan oleh Andiani (2018) menyatakan bahwa ukuran perusahaan tidak berpengaruh pada volatilitas harga 
saham, karena semakin besar ukuran perusahaan menunjukkan kondisi keuangan yang mampu mengurangi tingkat volatilitas harga saham selaras dengan Sorin (2016) serta Gill and Obradovich (2012).

Dari fenomena, teori, dan research gap oleh peneliti sebelumnya, maka peneliti tertarik untuk melakukan penelitian tentang nilai perusahaan. Penelitian ini membatasi penelitian terhadap faktor yang mempengaruhi nilai perusahaan, yaitu: likuiditas, kebijakan dividen, profitabilitas, dan ukuran perusahaan. Lebih lanjut, penelitian ini akan menggunakan saham-saham yang aktif sebagai sampel penelitian yaitu mengambil sampel dari perusahaan yang terdaftar dalam Indeks LQ 45 tahun 2013-2016. Tandelilin (2010) mengatakan indeks LQ 45 merupakan gabungan saham-saham dengan kategori unggulan dan terdiri dari 45 perusahaan dengan pendapatan stabil yang dipilih berdasarkan kriteria tertentu sehingga perusahaan dalam indeks LQ 45 dapat menjadi estimator yang baik. Selain itu, saham perusahaan yang masuk perhitungan indeks LQ 45 merupakan saham-saham dengan kapitalisasi besar yang mencakup 75\% kapitalisasi pasar sehingga dapat mewakili saham-saham yang tercatat di Bursa Efek Indonesia.

Tabel 1 Nilai Perusahaan Indeks Saham LQ 45 di BEI periode 20132016 diukur dengan PBV. 
Tabel 1.

Nilai Perusahaan Indeks Saham LQ 45 di BEI periode 2013-2016 diukur dengan PBV

\begin{tabular}{llcccc}
\hline NO & Kode & \multicolumn{3}{c}{ PBV } \\
& Emiten & 2013 & 2014 & 2015 & 2016 \\
\hline 1 & ADRO & 0.89 & 0.81 & 0.36 & 1.18 \\
2 & AKRA & 3.17 & 2.84 & 3.89 & 3.06 \\
3 & ASII & 2.59 & 2.60 & 1.92 & 2.54 \\
4 & GGRM & 2.75 & 3.66 & 2.78 & 3.27 \\
5 & ICBP & 4.48 & 5.26 & 4.79 & 5.61 \\
6 & INDF & 1.51 & 1.45 & 1.05 & 1.55 \\
7 & KLBF & 6.89 & 9.30 & 5.66 & 6.01 \\
8 & LSIP & 1.99 & 1.84 & 1.23 & 1.61 \\
9 & UNTR & 1.99 & 1.68 & 1.61 & 1.97 \\
10 & UNVR & 46.63 & 45.03 & 58.48 & 46.67 \\
\hline
\end{tabular}

Sumber : Data diolah, 2018

Pada Tabel 1 dapat dilihat bahwa adanya permasalahan yaitu terjadinya fluktuasi nilai perusahaan pada indeks saham LQ 45 periode 2013-2016. Fluktuasinya nilai perusahaan membuat ketidakpastian keuntungan yang dapat diperoleh pemegang saham. Hal inilah yang menjadi isu pokok dalam pelaksanaan penelitian.

Indeks LQ 45 diluncurkan oleh Bursa Efek Indonesia pada tanggal 24 Pebruari 2007 dengan nilai dasar awal adalah 100. Adapun perhitungan nilainya dimulai pada 1 Juli 1994 dengan nilai dasar awal adalah 100 dan menggunakan data saham pada periode juli 1993 sampai juni 1994. Adapun saham- saham yang masuk dalam Indeks LQ 45 akan di-review setiap 3 bulan sekali dimana akan dilihat apakah saham tersebut masih memenuhi kriteria yang diterapkan. Apabila saham tersebut tidak memenuhi kriteria seleksi yang dilakukan secara periodik maka saham itu akan digantikan oleh saham yang lain. Adapun pergantian saham dalam indeks LQ 45 tersebut dilakukan setiap 6 bulan sekali yaitu dilakukan pada bulan Pebruari dan bulan Agustus. 
Likuiditas merupakan kemampuan perusahaan untuk melunasi kewajiban finansialnya dalam jangka pendek dengan dana yang tersedia. Seperti membayar gaji, membayar biaya operasional, membayar utang jangka pendek dan yang lain yang membutuhkan pembayaran segera. Posisi dana lancar harus selalu lebih besar dari pada utang lancar, agar perusahaan dikatakan likuid yang menandakan perusahaan itu sehat. Perlu pengaturan untuk memelihara likuiditas yang sehat agar kredibilitas perusahaan juga tetap baik pada investor (Wiagustini, 2010:97).

Menurut Putra dan Lestari (2016) mengatakan tingkat likuiditas perusahaan diukur dengan posisi modal kerja perusahaan yang berjalan dari laba yang didapat dalam periode tertentu dimana modal tersebut dapat menunjukkan tingkat keamanan kewajiban jangka pendek. Kewajiban jangka pendek sering dibayar menggunakan aset lancar yang mudah dikonversi menjadi kas yang meliputi kas, piutang, surat berharga, piutang dan persediaan. Perusahaan yang memiliki aset lancar yang banyak akan lebih mudah untuk mendanai kegiatan operasionalnya. Menurut Menawati (2017) dengan hal tersebut tentu saja investor akan memberikan penilaian yang baik terkait dengan nilai perusahaan.

Kebijakan dividen berpengaruh terhadap likuiditas perusahaan, maka hal ini sangat penting karena berkaitan dengan cara untuk memaksimumkan nilai perusahaan. Untuk perusahaan yang mempunyai laba ditahan yang cukup, tetapi manajemen akan melakukan investasi-investasi pada proyek yang 
menguntungkan untuk prospek masa depan, maka perusahaan tidak bisa membagikan dividen tersebut dalam bentuk kas (Wiagustini, 2010:257).

Kenaikan pembagian dividen yang dilihat oleh investor akan dilihat sebagai sinyal bahwa prospek perusahaan dimasa mendatang itu baik (Iqbal Khan, 2012). Perusahaan go public mempunyai dampak penting bagi investor maupun perusahaan itu sendiri. Manajemen perusahaan harus bisa membuat kebijakan untuk memenuhi kebutuhan dana, investor bisa mendapatkan keuntungan agar tidak mengalihkan investasi ke perusahaan lain. Kebijakan dividen suatu perusahaan dapat dilihat dari nilai dividend payout ratio yaitu presentase laba yang dibagikan dalam bentuk dividen tunai.

Semakin tinggi nilai perusahaan, maka semakin tinggi kesejahteraan shareholdernya. Perusahaan dengan harga saham tinggi akan menunjukkan kinerja perusahaan itu baik, salah satunya adalah pandangan nilai perusahaan bagi pihak kreditur (Dewi dan Putri, 2017). Harga saham yang tinggi membuat nilai perusahaan juga tinggi. Nilai perusahaan lazim diindikasikan dengan price to book value (PBV). PBV yang tinggi akan membuat pasar percaya atas prospek perusahaan kedepan. Hal itu juga yang menjadi keinginan para pemilik perusahaan, sebab nilai perusahaan yang tinggi mengindikasikan kemakmuran pemegang saham juga tinggi (Dewi dan Wirawati, 2018)

Menurut Brigham dan Houston (2011) sinyal merupakan suatu tindakan yang diambil manajemen perusahaan yang dapat memberi petunjuk bagi investor tentang bagaimna manajemen memandang prospek perusahaan. Apabila rasio likuiditas meningkat maka mengindikasikan perusahaan mampu mengatasi 
kewajiban jangka pendek dengan baik, hal ini digunakan sebagai sinyal oleh manajemen untuk menarik investor untuk berinvestasi. Rasio likuiditas yang tinggi, image perusahaan akan semakin baik yang akan mengakibatkan harga saham meningkat dan membuat nilai perusahaan meningkat.

Rasio likuiditas berpengaruh pada nilai perusahaan, karena rasio likuiditas yang tinggi artinya, semakin besar utang jangka pendek bisa dilunasi. Sehingga investor tertarik pada perusahaan untuk melakukan investasi, sehingga permintaan saham perusahaan akan meningkat sehingga harga saham akan naik. Penelitian dilakukan oleh Menawati (2017) menunukkan likuiditas berpengaruh positif pada nilai perusahaan.

Berdasarkan uraian diatas dan penelitian sebelumnya, dapat dirumuskan hipotesis pertama sebagai berikut:

$\mathrm{H}_{1}$ : Likuiditas berpengaruh positif pada nilai perusahaan perusahaan

Dividen merupakan indikator yang sangat penting yang diharapkan oleh investor atas investasi yang dilakukan disuatu perusahaan. Dividen menjadi cerminan suatu perusahaan dalam menghasilkan laba, bila dividen yang diberikan tidak sesuai dengan harapan investor, maka akan muncul kecendrungan para pemilik saham menjual saham di perusahaan tersebut. Investor dapat menilai kebijakan dividen perusahaan melalui dividend payout ratio yang menunjukkan seberapa besar porsi keuntungan yang dibagikan oleh perusahaan untuk dijadikan dividen. Sehingga jika pembagian dividen besar, maka harga saham dan nilai perusahaan akan meningkat (Hanarista, 2016). 
Teori sinyal menekankan bahwa perusahaan dapat mengirimkan sinyal kepada pihak eksternal melalui pelaporan informasi terkait kinerja perusahaan, pasar akan merespon atas pengumuman pembagian dividen sehingga dapat memandang prospek perusahaan untuk masa mendatang (Devi dan Suardikha 2014). Berdasarkan teori Bird in the Hand adalah besarnya dividen yang dibagikan kepada pemegang saham karena sebagi investor lebih menyukai dividen ketimbang capital gain karena dividen lebih pasti. Akibatnya akan meningkatkan harga saham yang akan meningkatkan nilai perusahaan. Penelitian yang dilakukan oleh (Sorin 2016).

Berdasarkan uraian diatas dan penelitian sebelumnya, dapat dirumuskan hipotesis kedua sebagai berikut:

$\mathrm{H}_{2}$ : Kebijakan Dividen berpengaruh positif pada nilai perusahaan

Teori sinyal menjelaskan bagaimana perusahaan mengeluarkan sinyal berupa informasi yang menjelaskan keadaan perusahaan lebih baik dari perusahaaan lainnya. Salah satu informasi keuangan yang dikeluarkan adalah informasi keuangan yang menjelaskan kinerja keuangan yang diukur dengan rasio profitabilitas yang diproksikkan melalui Return on Assets (ROA). ROA Semakin baik kinerja suatu perusahaan maka akan semakin baik pula prospek perusahaan di masa mendatang yang artinya semakin baik juga nilai suatu perusahaan. Profitabilitas menunjukkan tingkat keuntungan bersih yang mampu diraih perusaan pada saat menjalankan operasinya (Dewi dan Putri 2017).

Apabila ROA meningkat akan menunjukkan kinerja keuangan yang semakin baik, karena tingkat pengembalian (return) semakin besar. Dampaknya 
adalah profitabilitas yang dinikmati pemegang saham akan meningkat. Penelitian dilakukan oleh Dewi dan Wirawati (2018) mengatakan profitabilitas berpengaruh positif pada nilai perusahaan selaras dengan penelitian Malino (2017), (Bertinetti (2013) dan Hoyt and Liebenberg (2011).

Berdasarkan uraian diatas dan penelitian sebelumnya, dapat dirumuskan hipotesis ketiga sebagai berikut:

$\mathrm{H}_{3}$ : Profitabilitas berpengaruh positif pada nilai perusahaan

Ukuran perusahaan merupakan salah satu acuan dalam menilai kinerja perusahaan (Lischewski and Voronkova 2012). Ukuran perusahaan yang besar menunjukkan bahwa perusahaan mengalami perkembangan, sehingga investor akan merespon secara positif dan nilai perusahaan akan meningkat (Sujoko and Soebiantaro 2007). Sehingga ukuran perusahaan yang besar akan memiliki daya tarik untuk memikat investor.

Perusahaan yang besar akan memiliki kondisi yang lebih stabil sehingga investor akan tertarik untuk membeli saham perusahaan tersebut. Maka, harga saham perusahaan dipasar modal akan meningkat. Hasil penelitian yang dilakukan oleh Lestari (2018) menyatakan ukuran perusahaan berpengaruh positif pada nilai perusahaan didukung pula oleh hasil penelitian (Rudangga and Sudiarta 2016).

Berdasarkan uraian diatas dan penelitian sebelumnya, dapat dirumuskan hipotesis keempat sebagai berikut:

$\mathrm{H}_{4}$ : Ukuran perusahaan berpengaruh positif pada nilai perusahaan. 


\section{METODE PENELITIAN}

Pendekatan yang digunakan dalam penelitian ini adalah pendekatan kuantitatif dan bersifat asosiatif. Sugiyono (2016) menyatakan bahwa penelitian asosiatif adalah penelitian yang bertujuan untuk mengetahui hubungan dua variabel atau lebih. Penelitian ini bertujuan untuk menguji likuiditas, kebijakan dividen, profitabilitas dan ukuran perusahaan pada nilai perusahaan. Penelitian ini menggunakan seluruh perusahaan indeks saham LQ 45 yang terdaftar di Bursa Efek Indonesia sebagai populasi dalam penelitian ini. Waktu penelitian ini yaitu periode 2013-2016.

Pengambilan sampel dilakukan dengan purposive sampling. Elemen populasi yang sebagai sampel dibatasi dengan pada elemen-elemen yang sahamnya masuk berturut-turut dalam Indeks LQ 45 di BEI secara berturutturut periode 2013-2016 dan perusahaan yang melaporkan laporan keuangan dalam satuan rupiah secara lengkap. Data yang digunakan adalah data sekunder, yaitu data yang tidak langsung diberikan kepada peneliti, karena harus melalui orang lain atau melalui dokumen. Data ini diperoleh melalui publikasi laporan keuangan tahunan yang telah diaudit perusahaan indeks LQ 45 tahun 2013-2016. Data yang diperoleh kemudian diolah menggunakan alat statistic SPSS untuk mengetahui apakah hipotesis diterima atau ditolak. Teknik analisis yang digunakan adalah regresi linear berganda. Persamaan regresi tersebut adalah sebagai berikut: 


$$
Y=\alpha+\beta_{1} X_{1}+\beta_{2} X_{2}+\beta_{3} X_{3}+\beta_{4} X_{4}+\varepsilon
$$

Keterangan:

$\begin{array}{ll}Y & : \text { Nilai Perusahaan } \\ \alpha & : \text { Konstanta } \\ \beta_{1}-\beta_{4} & : \text { Koefisien regresi dari setiap variabel independen } \\ \mathrm{X}_{1} & : \text { Likuiditas } \\ \mathrm{X}_{2} & : \text { Kebijakan Dividen } \\ \mathrm{X}_{3} & : \text { Profitabilitas } \\ \mathrm{X}_{4} & : \text { Ukuran perusahaan } \\ \varepsilon & : \text { Standar eror }\end{array}$

\section{HASIL PENELITIAN}

Analisis regresi linier berganda digunakan untuk mengetahui besarnya pengaruh Likuiditas $\left(\mathrm{X}_{1}\right)$, Kebijakan Dividen $\left(\mathrm{X}_{2}\right)$, Profitabilitas $\left(\mathrm{X}_{3}\right)$, dan Ukuran Perusahaan $\left(\mathrm{X}_{4}\right)$ pada Nilai Perusahaan $(\mathrm{Y})$ di perusahaan dalam indeks LQ 45 yang terdaftar di Bursa Efek Indonesia tahun 2013-2016. Hasil olahan data dengan SPSS menggunakan model analisis regresi linier berganda dapat dilihat sebagai berikut:

Tabel 2.

Hasil Analisis Regresi Linier Berganda

\begin{tabular}{|c|c|c|c|c|c|c|}
\hline \multirow{2}{*}{\multicolumn{2}{|c|}{ Model }} & \multicolumn{2}{|c|}{$\begin{array}{l}\text { Unstandardized } \\
\text { Coefficients }\end{array}$} & \multirow{2}{*}{$\begin{array}{c}\text { Standardized } \\
\text { Coefficients } \\
\text { Beta }\end{array}$} & \multirow[t]{2}{*}{$\mathrm{T}$} & \multirow[t]{2}{*}{ Sig. } \\
\hline & & B & Std. Error & & & \\
\hline \multirow[t]{8}{*}{1} & (Constant) & 1,871 & 7,168 & & 0,261 & 0,796 \\
\hline & $\mathrm{X}_{1}$ & 0,013 & 0,006 & 0,351 & 2,269 & 0,030 \\
\hline & $X_{2}$ & 0,022 & 0,028 & 0,130 & 0,784 & 0,438 \\
\hline & $X_{3}$ & 0,102 & 0,040 & 0,433 & 2,550 & 0,015 \\
\hline & $\mathrm{X}_{4}$ & $-0,167$ & 0,363 & $-0,072$ & $-0,459$ & 0,649 \\
\hline & Adjusted $\mathrm{R}^{2}$ & & & & & 0,614 \\
\hline & F Hitung & & & & & 5,303 \\
\hline & Sig. F & & & & & 0,002 \\
\hline
\end{tabular}

Dari hasil analisis regresi linier berganda pada Tabel 2 dapat dibuat persamaan sebagai berikut:

$$
\mathrm{Y}=1,871+0,013 \mathrm{X}_{1}+0,022 \mathrm{X}_{2}+0,102 \mathrm{X}_{3}-0,167 \mathrm{X}_{4}+\varepsilon
$$


Berdasarkan persamaan regresi di atas dapat dijelaskan bahwa nilai konstanta $(\alpha)$ sebesar 1,871 berarti apabila variabel bebas yaitu likuiditas, kebijakan dividen, profitabilitas dan ukuran perusahaan sama dengan nol, maka nilai perusahaan meningkat sebesar 1,871 satuan.

Nilai koefisien regresi likuiditas $\left(\beta_{1}\right)$ sebesar 0,013 berarti apabila likuitas meningkat sebesar 1 satuan dengan anggapan variabel lainnya konstan, maka nilai perusahaan akan meningkat sebesar 0,013 satuan.

Nilai koefisien regresi kebijakan dividen $\left(\beta_{2}\right)$ sebesar 0,022 berarti apabila kebijakan dividen meningkat sebesar 1 satuan dengan anggapan variabel lainnya konstan, maka nilai perusahaan akan meningkat sebesar 0,022 satuan.

Nilai koefisien regresi profitabilitas $\left(\beta_{3}\right)$ sebesar 0,102 berarti apabila profitabilitas meningkat sebesar 1 satuan dengan anggapan variabel lainnya konstan, maka nilai perusahaan akan meningkat sebesar 0,102 satuan.

Nilai koefisien regresi ukuran perusahaan $\left(\beta_{4}\right)$ sebesar $(-0,167)$ berarti apabila ukuran perusahaan meningkat sebesar 1 satuan dengan anggapan variabel lainnya konstan, maka nilai perusahaan akan menurun sebesar 0,167 satuan.

Uji statistik $\mathrm{t}$ bertujuan untuk mengetahui variabel bebas yang digunakan dalam persamaan regresi yaitu likuiditas, kebijakan dividen, profitabilitas, dan ukuran perusahaan secara individual (parsial) mampu menjelaskan variabel terikatnya yaitu nilai perusahaan.

Berdasarkan Tabel 2 pada persamaan diperoleh nilai signifikansi Uji t untuk variabel likuiditas sebesar 0,030 lebih kecil dari 0,05 dan nilai koefisien 
regresi sebesar 0,013. Menunjukkan variabel likuiditas berpengaruh positif pada nilai perusahaan. Sehingga hipotesis pertama dalam penelitian ini diterima.

Berdasarkan Tabel 2 pada persamaan diperoleh nilai signifikansi Uji t untuk variabel kebijakan dividen sebesar 0,438 lebih besar dari 0,05 dan nilai koefisien regresi sebesar 0,022. Menunjukkan variabel kebijakan dividen tidak berpengaruh pada nilai perusahaan. Sehingga hipotesis kedua dalam penelitian ini ditolak.

Berdasarkan Tabel 2 pada persamaan diperoleh nilai signifikansi Uji t untuk variabel profitabilitas sebesar 0,015 lebih kecil dari 0,05 dan nilai koefisien regresi sebesar 0,102. Menunjukkan variabel profitabilitas berpengaruh positif pada nilai perusahaan. Sehingga hipotesis ketiga dalam penelitian ini diterima.

Berdasarkan Tabel 2 pada persamaan diperoleh nilai signifikansi Uji t untuk variabel ukuran perusahaan sebesar 0,649 lebih besar dari 0,05 dan nilai koefisien regresi $(-0,167)$. Menunjukkan variabel ukuran perusahaan tidak berpengaruh pada nilai perusahaan. Sehingga hipotesis keempat dalam penelitian ini ditolak.

Berdasarkan hasil yang disajikan pada Tabel 2 pada persamaan diperoleh nilai signifikansi Uji t untuk variabel likuiditas sebesar 0,030 lebih kecil dari nilai taraf nyata 0,05 atau nilai $0,030<0,05$ maka $\mathrm{H}_{1}$ diterima. Jadi dapat disimpulkan bahwa variabel likuiditas berpengaruh positif pada nilai perusahaan. Hasil penelitian ini sesuai dengan logika teori sinyal yang menekankan bahwa segala tindakan yang diambil manajemen untuk memberi informasi sinyal kepada investor mengenai rasio likuiditas. Ini berarti rasio likuiditas yang tinggi 
mengindikasikan perusahaan mampu melunasi kewajiban jangka pendek yang akan membuat image perusahaan menjadi baik. Maka harga saham akan naik yang akan membuat nilai perusahaan meningkat. Naik turunnya nilai perusahaan yang terdaftar dalam Indeks LQ 45 di BEI tahun 2013-2016 dipengaruhi oleh likuiditas. Hasil penelitian ini sesuai dengan temuan Menawati (2016), Rompas (2013) dan Mahendra dkk. (2012) yang menyatakan likuiditas berpengaruh positif pada nilai perusahaan.

Berdasarkan hasil yang disajikan pada Tabel 2 pada persamaan diperoleh nilai signifikansi Uji t untuk variabel kebijakan dividen sebesar 0,438 lebih besar dari nilai taraf nyata 0,05 atau nilai $0,438>0,05$ maka $\mathrm{H}_{1}$ ditolak. Jadi dapat disumpulkan bahwa variabel kebijakan dividen tidak berpengaruh pada nilai perusahaan. Penelitian ini tidak sesuai dengan logika teori sinyal tentang bagaimana seharusnya sebuah perusahaan memberikan sinyal dimana melalui pelaporan informasi terkait kinerja perusahaan, pasar akan merespon atas pengumuman pembagian dividen sehingga dapat memandang prospek perusahaan untuk masa mendatang dan juga tidak sesuai dengan bird in the hand theory. Menurut teori yang dividen adalah tidak relevan yang dikemukakan oleh Miller dan Modigliani yang mengemukakan bahwa kebijakan tidak berpengaruh pada nilai perusahaan karena rasio pembayaran dividen hanyalah rincian dan tidak mempengaruhi kesejahteraan pemegang saham. Meningkatnya nilai dividen tidak selalu diikuti dengan meningkatnya nilai perusahaan karena nilai perusahaan hanya ditentukan oleh kemampuan perusahaan menghasilkan laba dari aset-aset perusahaan (Mardiyanti, dkk. 2012). Hasil penelitian ini sesuai dengan temuan 
Nurhayati (2013) dan Sukirini (2012) yang menyatakan kebijakan dividen tidak berpengaruh terhadap nilai perusahaan.

Berdasarkan hasil yang disajikan pada Tabel 1 pada persamaan diperoleh nilai signifikansi Uji t untuk variabel profitabilitas sebesar 0,015 lebih kecil dari nilai taraf nyata 0,05 atau nilai $0,015<0,05$ maka $\mathrm{H}_{1}$ diterima. Jadi dapat disimpulkan bahwa variabel profitabilitas berpengaruh positif pada nilai perusahaan. Penelitian ini dapat membuktikan teori sinyal yang menyatakan bahwa informasi yang dikeluarkan perusahaan dapat berupa informasi keuangan yang menunjukkan kinerja keuangan yang diukur dengan rasio profitabilitas yang diproksikkan melalui return on assets (ROA). Profitabilitas menunjukkan tingkat keuntungan bersih yang mampu diraih perusahaan pada saat menjalankan operasinya (Dewi, 2017). Apabila ROA meningkat return yang diterima pemegang saham akan meningkat. Hasil penelitian ini sesuai dengan penelitian yang dilakukan oleh Indasari (2017), Irma (2014) dan Ismail (2015).

Berdasarkan hasil yang disajikan pada Tabel 1 pada persamaan diperoleh nilai signifikansi Uji t untuk variabel ukuran perusahaan sebesar 0,649 lebih besar dari nilai taraf nyata 0,05 atau nilai $0,649>0,05$. Maka $\mathrm{H}_{1}$ ditolak. Jadi dapat disimpulkan variabel ukuran perusahaan tidak berpengaruh pada nilai perusahaan. Ukuran perusahaan yang besar dapat menyebabkan ketidakefisienan operasi perusahaan dalam berproduksi dan berdampak pada tidak optimalnya dalam menghasilkan laba. Investor yang melihat hal tersebut tidak akan tertarik untuk menanamkan sahamnya dan harga saham akan menurun berdampak pada nilai 
perusahaan yang rendah. Hasil penelitian ini sesuai dengan Wijanti dan Sedana (2013).

Penelitian ini menghasilkan simpulan mengenai bagaimana pengaruh likuiditas, kebijakan dividen, profitabilitas, dan ukuran perusahaan pada nilai perusahaan. Hasil dari penelitian ini dapat memberikan referensi sebagai acuan di dalam melakukan investasi di pasar modal, dengan memerhatikan faktor-faktor yang dapat mempengaruhi nilai perusahaan. Penelitian ini dapat membuktikan teori sinyal dimana informasi-informasi yang dikeluarkan oleh perusahaan dapat menjadi sinyal bagi pihak di luar perusahaan, informasi tersebut dapat berupa informasi keuangan yang dibutuhkan bagi investor yaitu laporan keuangan tahunan perusahaan yang dapat memberikan petunjuk bagi investor tentang bagaimana manajemen memandang prospek perusahaan agar investor dapat mengambil keputusan berinvestasi yang selanjutnya berdampak pada nilai perusahaan. Penelitian ini juga membuktikan tidak semua variabel yang secara teori memengaruhi nilai perusahaan ketika dilakukan penelitian berpengaruh secara nyata, hal ini dapat terjadi karena adanya perbedaan obyek penelitian, periode penelitian, dan kondisi yang berbeda.

Penelitian ini diharapkan akan memberikan kontribusi positif bagi semua pihak khususnya pihak perusahaan dan investor. Bagi pihak perusahaan hendaknya memperhatikan pencapaian investasi saham yang optimum bagi perusahaan melalui kenaikan laba yang konsisten dan asset perusahaan yang mampu meningkatkan harga saham. Bagi pihak investor dalam berinvestasi di pasar modal tetap memperhatikan tingkat likuiditas, kebijakan dividen, 
profitabilitas dan ukuran perusahaan yang akan diinvestasikan, karena dilihat dari koefisien determinasi sebesar 30,6\% dapat menjelaskan tingkat nilai perusahaan. Untuk meminimalisir kesalahan dalam berinvestasi di pasar modal.

\section{SIMPULAN}

Berdasarkan hasil analisis dan pembahasan yang telah dipaparkan maka didapatkan simpulan bahwa likuiditas berpengaruh positif pada nilai perusahaan. Kebijakan dividen tidak berpengaruh pada nilai perusahaan. Profitabilitas berpengaruh positif pada nilai perusahaan. Ukuran perusahaan tidak berpengaruh terhadap nilai perusahaan.

Berdasarkan simpulan di atas, saran-saran yang dapat diberikan berkaitan dengan hasil penelitian serta untuk kesempurnaan penelitian selanjutnya yaitu penelitian ini hanya menggunakan faktor internal yaitu likuditas, kebijakan dividen, profitabilitas dan ukuran perusahaan dalam menentukan nilai perusahaan. Penelitian selanjutnya diharapkan dapat membahkan faktor eksternal sebagai variabel di dalam menentukan nilai perusahaan seperti tingkat inflasi dan tingkat suku bunga. Selain itu peneliti selanjutkan juga dapat melakukan penelitian yang serupa dengan mengambil sektor perusahaan yang berbeda agar hasil yang diperoleh nantinya memiliki cakupan lebih luas dan melibatkan faktor internal dan eksternal dalam menentukan nilai perusahaan.

Bagi perusahaan di Indonesia selalu mempertimbangkan pengaruh likuiditas dan profitabilitas agar dapat mengevaluasi faktor-faktor tersebut untuk 
menjadi pertimbangan dalam meningkatkan nilai perusahaan karena investor lebih berminat untuk berinvestasi diperusahaan dengan nilai perusahaan yang tinggi.

Bagi investor dalam berinvestasi di pasar modal tetap memperhatikan laporan keuangan sebagai dasar untuk pengambilan keputusan investasi. Investor merupakan bagian dari masyarakat hendaknya lebih berhati-hati dan teliti dalam membaca informasi keuangan sehingga investor dapat mengambil keputusan dengan tepat.

Penelitian ini hanya menggunakan faktor internal yaitu likuditas, kebijakan dividen, profitabilitas dan ukuran perusahaan dalam menentukan nilai perusahaan. Penelitian selanjutnya diharapkan dapat membahkan faktor eksternal sebagai variabel di dalam menentukan nilai perusahaan seperti tingkat inflasi dan tingkat suku bunga. Selain itu peneliti selanjutkan juga dapat melakukan penelitian yang serupa dengan mengambil sektor perusahaan yang berbeda agar hasil yang diperoleh nantinya memiliki cakupan lebih luas dan melibatkan faktor internal dan eksternal dalam menentukan nilai perusahaan.

\section{REFERENSI}

Adesola, WA, and AE Okwong. 2009. An Imperical Study of Divident Policy of Quoted Companies in Nigeria. Global Journal of Social Sciences, 8(1). pp:85-101. http://www.ajol.info/index.php/gjss/article/view/48907.

Agrawal, Surendra., Reza M. Monem, and Mohamed Ariff. 1996. Price to Book Ratio as a Valuation Model: An Empirical Investigation.Finance India, 10(2):

http://citeseerx.ist.psu.edu/viewdoc/download?doi=10.1.1.570.3053\&rep=rep $1 \&$ type $=$ pdf.

Ahmad Attari, Muneeb, and Kashif Raza. 2012. The Optimal Relationship of Cash Conversion Cycle with Firm Size and Profitability.International 
Journal of Academic Research in Business and Social Sciences 2(4): 22226990. www.hrmars.com/journals.

Andiani, Sekar 2018. Pengaruh Volume Perdagangan Saham, Volatilitas Laba, Dividend Yield, dan Ukuran Perusahaan Pada Volatilitas Harga Saham (Studi Empiris Pada Perusahaan yang Terdaftar dalam Indeks LQ 45 Tahun 20122016). E-Jurnal Akuntansi Universitas Udayana, 24(1)h : 2148-2175.

Astutik, Dwi. 2017. Pengaruh Aktivitas Rasio Keuangan Terhadap Nilai Perusahaan (Studi Pada Industri Manufaktur).STIE Semarang, 9(1): 32-49.

Badera, I Dewa Nyoman, and Ni Putu Santi Dewantari. 2015. Good Corporate Governance, Ukuran Perusahaan, Dan Financial Leverage Sebagai Prediktor Perataan Laba. E-Jurnal Akuntansi Universitas Udayana 10(2): 538-53.

Brigham, Eugene F. dan Houston, Joel F. 2011. Dasar-dasar Manajemen Keuangan. Terjemahan. Edisi 10. Jakarta: Salemba Empat.

Bursa Efek, 2000. JSX Fact Book 2000. Jakarta.

Bertinetti, Giorgio Stefano, Elisa Cavezzali, and Gloria Gardenal. 2013. The Effect of the Enterprise Risk Management Implementation on the Firm Value of European Companies. Working Paper Series No. 10. ISSN: 2239-2734

Budi, I Wayan, and I G A M Asri Dwija Putri. 2018. Pengaruh Struktur Kepemilikan, Ukuran Perusahaan Dan Kebijakan Dividen Pada Manajemen Laba Riil. E-Jurnal Akuntansi Universitas Udayana 25(1) h: 109-134.

Dewi, dan I G A M Asri Dwija Putri. 2017. Pengaruh Kebijakan dividen Pada Nilai Perusahaan dengan Pengungkapan CSR dan GCG sebagai Pemoderasi. E-Jurnal Akuntansi Universitas Udayana, 21(1) h: 173-99.

Devi, dan I Made Sadha Suardikha. 2014. Pengaruh Profitabilitas Pada Kebijakan Dividen Dengan Likuiditas Dan Kepemilikan Manajerial Sebagai Variabel Pemoderasi. E-Jurnal Ekonomi dan Bisnis Unud ,12(3): 702-17.

Dewi, Anak Agung Ayu Tisna Wulan, and Ni Gst. Putu Wirawati. 2018. Pengaruh Profitabilitas Pada Nilai Perusahaan Dengan Corporate Social Responsibility Sebagai Variabel Intervening." E-Journal Akuntansi Universitas Udayana 22(2): 1557-83.

Dwipayana, Made Agus Teja, and I. Gst. Ngr. Agung Suaryana. 2016. Pengaruh Debt to Assets Ratio, Devidend Payout Ratio, Dan Return on Assets Terhadap Nilai Perusahaan." E-Jurnal Akuntansi Universitas Udayana 17(3): 2008-2035. https://ojs.unud.ac.id/index.php/Akuntansi/article/view/22313. 
Gill, Amarjit, and John D Obradovich. 2012. The Impact of Corporate Governance and Financial Leverage on the Value of American Firms. International Research Journal of Finance and Economics 9: 1-14.

Gryglewicz, Sebastian. 2011. A Theory of Corporate Financial Decisions with Liquidity and Solvency Concerns. Journal of Financial Economics 99(2): 365-84. http://dx.doi.org/10.1016/j.jfineco.2010.09.010.

Hartono, Jogiyanto. 2010. Teori Portofolio dan Analisis Investasi. Edisi Tujuh. Yogyakarta : BPFE-Yogyakarta.

Hoyt, Robert E., and Andre P. Liebenberg. 2011. The Value of Enterprise Risk Management: Evidence from the US Insurance Industry." Unpublished Paper: 1-2.

Hugida, Lydianita. 2011. Analisis Faktor-Faktor Yang Mempengaruhi Volatilitas Harga Saham (Studi Pada Perusahaan Yang Terdaftar Dalam Indeks LQ45 Periode 2006-2009). Universitas Diponegoro.

Iqbal Khan, Kanwal. 2012. Effect of Dividends on Stock Prices- A Case of Chemical and Pharmaceutical Industry of Pakistan. Management 2(5): 14148. http://article.sapub.org/10.5923.j.mm.20120205.02.html.

Izah, Mohd Tahir, and Rizal Razali Ahmad. 2011. The Relationship between ERM and Firm Value: Evidence from Malaysian Public Listed Companies." International Journals Economics and Management Science 1(2): 32-41.

Kartika, Andi, Elen Puspitasari, and Bambang Sudiyatno. 2012. The Company's Policy, Firm Performance, and Firm Value: An Empirical Research on Indonesia Stock Exchange." American International Journal of Contemporary $\quad$ Research 2(12): 30-40. http://www.aijcrnet.com/journals/Vol_2_No_12_December_2012/4.pdf.

Lischewski, Judith, and Svitlana Voronkova. 2012. Size, Value and Liquidity. Do They Really Matter on an Emerging Stock Market? Emerging Markets Review 13(1): 8-25.

Malik, Muhammad Farhan, Muhammad Usman Qureshi, and Muhammad Azeem. 2012. Determination of Share Price: Evidence from Karachi Stock Exchange.The Romanian Economic Journal, XV(43): 97-114.

Malino, Muhammad Ryan Yanuar Daeng. 2017. Pengaruh Profitabilitas Dan Kepemilikan Manajerial Pada Nilai Perusahaan Dengan Pengungkapan Csr Sebagai Variabel Pemoderasi." E-Jurnal Akuntansi Universitas Udayana 21(3): 2052-80. 
Menawati dan Putra Astika. 2017. Pengaruh Rentabilitas dan Likuiditas Pada Jumlah Opsi Saham dan Dampaknya Pada Nilai Perusahaan. E-Jurnal Akuntansi Universitas Udayana 18(3) h: 1915-42.

Octaviani, Ni Kadek Dewi, and Ida Bagus Putra Astika. 2016. Profitabilitas Dan Leverage Sebagai Pemoderasi Pengaruh Kebijakan Dividen Pada Nilai Perusahaan.”E-Jurnal Akuntansi Universitas Udayana , 3(2) h: 2192-2219.

Prasetyorini, Bhekti Fitri. 2013. Pengaruh Ukuran Perusahaan, Leverage, Price Earning Ratio dan Profitabilitas terhadap Nilai Perusahaan. Jurnal Ilmu Manajemen, 1(1): 183-96.

Pratama, I.G.B dan I Gusti Bagus Wiksuana. 2016. Pengaruh Ukuran Perusahaan dan Leverage terhadap Nilai Perusahaan dengan Profitabilitas sebagai Variabel Mediasi. E-Jurnal Manajemen Universitas Udayana, 5 (2), h: 1338-1367. Brigham, E. F. dan Gapensi, L. C. 2006. Intermediate Financial Management, $7^{\text {th }}$ edition. Sea Harbor Drive: The Dryden Press.

Putra, AA Ngurah Dharma Adi, and Putu Vivi Lestari. 2016. Pengaruh Kebijakan Dividen, Likuiditas, Profitabilitas Dan Ukuran Perusahaan Terhadap Nilai Perusaan. E-Jurnal Manajemen Universitas Udayana, 5(7): 4044-4070.

Rudangga, I Gusti Ngurah Gede, dan Gede Merta Sudiarta. 2016. Pengaruh Ukuran Perusahaan, Leverage dan Profitabilitas Terhadap Nilai Perusahaan." E-Jurnal Manajemen Unud, 5(7): 4394-4422.

Sari, Indah Kusuma dan Yasa, Gerianta Wirawan. 2016. Pengaruh Peneapan Good Corporate Governance, Profitabilitas, dan Likuiditas terhadap Peringkat Obligasi (Bond Ratings). E-Jurnal Akuntansi Universitas Udayana, 17(3):h:2198-2224.

Senata, Maggee. 2016. Pengaruh Kebijakan Dividen Terhadap Nilai Perusahaan Yang Tercatat Pada Indeks Lq-45. Jurnal Wira Ekonomi Mikrosil, 6(01): 7384.

Sorin, Gabriel ANTON. 2016. The Impact of Dividend Policy On Firm Value. A Panel Data Analysis of Romanian Listed Firms. Journal of Public Administration, Finance and Law THE 1(10): 107-12. http://www.jopafl.com/uploads/issue10/The_Impact_Of_Dividend_Policy_O n_Firm_Value_A_Panel_Data_Analysis_Of_Romanian_Listed_Firms.Pdf.

Sujoko, and U. Soebiantaro. 2007. Shareholding Structure Influence Leverage Factor Internal And External Factors Against Value Company (Empirical Study on the Manufacturing and Non-Manufacturing Companies in Jakarta Stock Exchange)."Journal of Management and Entrepreneurship, 9(1976): 
pp.41-48.

Surya Lestari, Nita. 2018. Pengaruh Ukuran Perusahaan Dan Pengungkapan CSR Terhadap Nilai Perusahaan Dengan GCG Sebagai Variabel Pemoderasi." EJournal Akuntansi Universitas Udayana, 23 (2) h:1386-1414. https://ojs.unud.ac.id/index.php/Akuntansi/article/view/37565.

Susianti, Maria dan Gerianta Wirawan Yasa. 2013. Pengaruh Kinerja Keuangan Terhadap Nilai Perusahaan dengan Pemoderasi Good Corporate Governance dan Corporate Social Responsibility. E-Jurnal Akuntansi Universitas Udayana, 3(1), h:73-91.

Suniari, Melina dan I G N Agung Suaryana. 2017. Pengaruh Umur dan Ukuran Perusahaan Pada Pengungkapan Modal Intelektual dan Dampaknya terhadap Nilai Perusahaan. E-Jurnal Akuntansi Universitas Udayana, 21(2), h:15491574.

Tandelilin, Eduardus. 2010. Analisis Investasi Dan Manajemen Portofolio. Edisi 7. Yogyakarta: Kanisius.

Topaloğlu, Rezan et al. 2010. Neuroendocrine Immune System in Familial Mediterranean Fever. Turkish Journal of Pediatrics, 52(6): 588-93. http://dx.doi.org/10.1016/j.jfineco.2008.08.007.

Uremadu, Sebastian Ofumbia, Ben-Caleb Egbide, and Patrick E. Enyi. 2012. Working Capital Management, Liquidity and Corporate Profitability Among Quoted Firms in Nigeria Evidence from the Productive Sector. International Journal of Academic Research in Accounting, Finance and Management Sciences 2(1): 80-97. http://ideas.repec.org/a/hur/ijaraf/v2y2012i1p8097.html.

Uwigbe, Uwalomwa, Jimoh JAFARU, and Anijesushola AJAYI. 2018. Dividend Policy and Firm Performance: A Study of Listed Firms in Nigeria. International Journal of Advanced Educational Research, 286(1): 286289.

Wiagustini, Ni Luh Putu. 2010. Dasar-dasar Manajemen Keuangan. Denpasar: Udayana University Press.

Wirasedana, I Wayan Pradnyantha. 2018. Pengaruh Keputusan Investasi , Keputusan Pendanaan, Kebijakan Dividen Dan Tingkat Inflasi Terhadap Nilai Perusahaan. E-Jurnal Akuntansi Universitas Udayana, 23(1) h: 813841. 